\title{
Determinants of Purchase Intention: An Interpretive Structural Modelling Approach
}

\author{
Trishala Chauhan* \\ *Research scholar, \\ School of Management, The Northcap University, Gurugram, Haryana, India \\ Dr. Ruchi Nayyar \\ *Assistant Professor, \\ School of Management, The Northcap University, Gurugram, Haryana, India
}

\begin{abstract}
In the present paper, the factors which impact consumer behavior are explored through extensive literature review. Also, common determinants of online and offline consumer behavior are identified. Subsequently, ISM approach is used to find the inter-relationship among these factors. Finally, ISM model depicting this interrelationship is developed and MICMAC analysis is performed to categorize factors into clusters depending on their drive and dependence power. Identified factors common to both offline and online buying behavior include convenience, promotion, availability, brand image, demography, safety, quality, word of mouth and price. ISM reveals that promotion, brand image, demography, quality and price are the linking factors with strong dependence and driving power. Additionally, convenience, availability and safety have emerged as the independent factors with strong driving power and weak dependence power.
\end{abstract}

Keywords: Offline buying. online buying. Determinants. ISM (Interpretive structural modelling). MICMAC

DOI: $10.7176 / \mathrm{JMCR} / 68-02$

Publication date:May $31^{\text {st }} 2020$

\section{Introduction}

Increase in the number of e-commerce websites has led to a steep rise in global online shopping. At the same time, the significance of offline shopping cannot be overlooked. This paper attempts to find factors that affect consumer behavior while buying products and services offline as well as online. Key objectives of this paper are (a.) to find factors which are common to both offline and online shopping and (b.) to develop an interrelationship among these factors. Eight factors are considered for study. These include convenience, promotion, availability, brand image, demography, safety, quality and price. Inter-relationship among these factors is analyzed through ISM approach. Further, the factors are classified on the basis of driving and dependence power through MICMAC analysis.

In the remainder paper, factors affecting offline and online buying behavior from literature are given in sections 2 and 3 respectively. Section 4 depicts the diagrammatic representation of offline and online factors with the clubbing of common factors and their references/sources. Section 5 depicts the ISM model generation and in Section 6, MICMAC analysis is performed. The conclusion and limitations are provided in sections 7 and 8 respectively.

\section{Offline buying behavior}

Offline purchase is a conventional way of purchasing products and undertaking services by directly visiting the store/shop or vendor.

Sethi, Inderjeet (2018) have explored that the most significant factors affecting consumer behavior in telecom industry includes promotion, social class, perception, religion. As per Legeza \& Brunner (2019) the major social factors for buying eco-intelligent products are employment status and store location. Rana, Jyoti \& Paul, Justin (2017) found that the factors which influence a consumer to buy organic products include health consciousness, expectation of wellbeing, quality and safety, willingness to pay, fashion trend, social consciousness and found that lack of promotion and distribution affects the presence of green products in developing countries. Shende, Vikram (2014) indicated that disposable income is the most influential factor for an automobile passenger car customer. Chopra (2014) conducted a study on factors influencing consumer behavior for cosmetic products and found that promotional strategy, festive offer discount, availability, billing speed and ambience to be most significant. Diallo et al. (2013) concluded that value consciousness to be major factor impacting consumer behavior towards store brand in French market. Lakshmi, Niharika, Lahari (2017) conducted a study to find the impact of gender on consumer purchasing behavior and the findings indicated that gender significantly influence consumer purchasing behavior. Kumar, John, Senith (2014) revealed that there existed significant differences among income level and behavior dimensions like social and cultural factors but no significant differences existed of income level with personal and psychological factors. Rengarajan, et al. (2014) indicated that income level is the most influential factor affecting consumer behavior for selected brands of milk products. 
Raj et al. (2013) found out that price and word of mouth are significant factors affecting consumer brand preference for SUV's and MUV's. Furaiji et al. (2012) established that cultural, social, personal, psychological variable weakly associate to consumer behavior. Prasad (2014) found out that consumers give more preference to latest design and availability of options and less preference to advertisement and trust. Mittal (2016) found that product features, social status and family are strongly associated with consumer buying behavior in Indian white goods industry. Kumar \& Namavaram (2016) concluded that price consciousness and coupon redemption are positively related to consumer behavior for selection of cab services. Horsu \& Solomon (2015) found out that comfort, affordability, reliability, and continuous service significantly impact customer satisfaction in minicab taxi services. Sata, Mesay (2013) revealed that price is the most influential factor followed by product features and durability while buying mobile phones. Peng, L et al. (2014) found perceived ease of use, perceived usefulness, compatibility, subjective norms , and perceived risk as key factors affecting consumer to avail call taxi app services. Also, durability, brand image strongly influence consumer buying behavior of mobile phone devices while after sales services and social influences weakly impact mobile phone devices purchase. Frank and Agnes (2018) revealed that the factors affecting purchase behavior for Patanjali brand in Mangalore are effective advertisement, best quality, reasonable price, wide range of products, brand image, attractive packaging, sales promotion and Baba Ramdev as brand ambassador. Kaveri \& William (2015) concluded that retailer's scheme and services are influential factors determining consumer behavior toward gold jewelry.

According to Kumar et al. (2017), major factors impacting consumer satisfaction in food outlets are hygiene, cleanliness, healthy food, service quality and physical environment. Pecotic et al.(2014) found that furniture comfort, music style and condition of tableware are most influential factors affecting customer satisfaction for interior design. Olise, et al. (2015) revealed using classic belief attitude behavior intention model that service quality, perceived value, environment, customer demographics and modernity to be significant factors influencing customer patronage of fast food restaurant. Rashid, Abdullah, Yusuf (2014) concluded that food served hot and fresh and correct and complete order are the factors considered important for customer satisfaction among gen $Y$ for fast food restaurant in Malaysia. Thabiso \& Sukdeo (2018) found that quality, features and price are the major factors affecting buying behavior for durable products while age does not have any significant impact. Altekar \& Keskar (2014) found out that style, Advertising, family members, friends and relatives, financing agency are the most influential factors in buying decision for durable products. Gomathy \& Devi (2015) found that consumer purchase gold for investment purpose which may help them during the emergency time. Yonas, Rasheed, Zia (2015) conducted a study to find the major factors influencing consumer purchase intention and found that customer knowledge, celebrity endorsement and product packaging has significant influence on consumer purchase intention whereas perceived value does not have any impact on consumer purchase intention. Khuong \& Duyen (2016) found out that self-image has the strongest influence other factors being skin health attention, body attraction, age and ageing process has moderate influence on consumer purchase decision for men's skin care products.

Koshy Ligo \& Manohar S John (2017) conducted a study to find factors influencing face care products among youth and found out that male customers give more importance to brand image, advertisement, and price respectively. SS Anjana (2018) found that quality and price are amongst the strongest factors influencing customer to buy cosmetic products. Kumar et al. (2014) found that dimensions like social, cultural are the factors influencing consumers to purchase cosmetic products. Showrav et al. (2018) found three major factors influencing consumer behavior for buying cosmetic products in Dhaka city to be consumer perception, external influence and psychological motives (includes looking beautiful, opposite gender and being socially responsible). Zulqarnain et al.(2015) conducted a study in selecting retail stores for grocery shopping and found that convenience, variety, prices, product quality and location are the most significant factor. Singh, Surabhi (2018) conducted a study to find the consumer buying behavior for buying perfume in India and found that fragrance as the most significant factor. Srivastava, Shalini (2013) performed a research to understand the factors affecting buying behavior of consumers for FMCG products and found that reliability and product attributes play a very significant role for low segment category of people in India. On the other hand, Chatterjee (2018) found co-branding, liberalization of economy to be having highest value for consumer buying motives in FMCG sector among advertising strategy, brand influence, co-branding, retail loyalty products, visual merchandising etc. According to Dande,R et al.(2018) factors that plays a major role for patient in selection of a dental hospital and dentist include distance from home to clinic, recommendations, word of mouth, behavior and communication skills of doctor and fame of doctor. Richard et al. (2016) explored the factors which a consumer finds significant while selecting a hotel and concludes that reviews of friend, cost effectiveness ,building professional relationship , location and security aspect and religion under cultural factor plays a significant role .Zulqarnain et al.(2015) found that the factors which customer takes into account while choosing a retail store for grocery shopping appeared to be quality, variety and location. Dubey et al.(2018) conducted a study of Vishal mega mart retail store to know the factors that consumer takes into account while shopping there and found that Vishal merchandising has a strong impact on impulse buying of shopper, layout of store as well as services offered by employees played an important role in buying products 
from Vishal mega mart.

\section{Online Buying Behavior}

Online shopping is a form of buying goods and availing services through internet without actually visiting the stores.

Chincholkar \&Sonwaney (2017) found that the most significant factors which consumer consider while selecting a website for shopping are availability and quality of products/services and also there is no significant difference existed between men's and women's attitude towards website.

Shanthi, Kannaiah (2015) revealed that price is the most significant factor impacting consumer to buy online followed by security, guarantees and warrantees. According to Vikash \& Kumar (2017) quality, convenience, satisfaction, availability of products, security and privacy, quickness, attractive, flexibility, spatial convenience and awareness are the most significant factors influencing consumer to buy online. Vadivu (2015) found that variety, quick service and reduced price are the most influential factors for consumer to buy online. Islam, Md. Shariful (2015) proposed a conceptual model consisting of independent variable as financial risks, convenience risks, non-delivery risk, infrastructural variables, return policy, attitude and subjective norms whereas dependent variables being attitude, online shopping behavior. The findings are such that financial risks and non-delivery risks have a negative effect on consumer attitude for online buying behavior. Nagra, Gopal (2013) concluded that age, gender, income, family size, marital status has a positive impact on online shopping behavior of consumers. According to Abdullah et al. (2016) the most influential factors for consumer buying stimuli are perceived ease of use, vendors characteristics, perceived usefulness and website design. Vaghela, Pratiksinh (2016) revealed that factors such as perceived ease of use, perceived usefulness, website design are the most influential factors affecting online shopping behavior of consumer. Further it is found out that there is no significant difference existed between male and female purchase behavior. Raunaque, Zeeshan, Imam (2016) concluded that easy return and refund policy, money back guarantee are among the factors to improve customer trust and hence the perception towards online shopping. Deshmukh \& Sanskrity (2016) revealed that demographic factors, product features, website design has the most significant influence on consumer to buy online. Singh et al. (2016) concluded that Gen Y has a positive bend towards online shopping and they prefer to shop anytime they feel like. Dange \& Kumar (2012) proposed a model factor, filtering element and filtered buying behavior (FFF). Factor (internal and external) make consumer to get into filtering elements (security concerns, privacy concerns, trust) which leads to filtered buying. Rao et al. (2018) found the factors which women consider important while purchasing online are ease of use, convenience, security, utility, time effectiveness, outbound logistics and feedback. Bauboniene \& Guleviciute (2015) revealed that the major factors impacting consumers to do online shopping are convenience, simple to access and relatively better prices. Mahalaxmi \& Ranjith (2016) concluded that the consumers are aware of digital marketing and give preference to digital channels to purchase any types of products. Rai (2018) revealed that consumer prefer to use digital channels to buy any sought of products irrespective of their monthly income.

Prasath \& Yaganathen (2018) concluded that SMM (social media marketing) as an independent variable has a positive and linear relationship with CBDM (consumer buying decision making) the dependent variable. Yapa (2017) conducted a study to find the effect of independent variables i.e. (users generated communication and firms generated communication) on dependent variables i.e. Brand awareness. Results stated that independent variables have positive correlation with dependent variables. Ioanas \& Stoica (2014) concluded that social media has a positive influence on online buying behavior of consumers. Emir et al.(2016) with the aid of stimulus-OrganismResponse model concluded that while booking hotel online consumer consider stimuli as independent variables (information quality, perceived interactivity, safety and privacy, price and promotion and e-word of mouth ) expected to influence perceived value (organism) which will lead them to book hotel online(response).Ahmed et al. (2018) concluded that perceived benefits, domain specific innovativeness and shopping orientation had significant and positive relation with consumer buying behavior. Whereas Jadhav \& Khanna (2016) conducted a study among college students to know the online buying behavior and found that availability, low price, promotions, comparison, convenience, customer service, ease of use, attitude, time consciousness, trust and variety seeking to be the most influential factors considered for online purchase. Akbar et al. (2017) revealed that quality is the most significant factor followed by convenience and trust while promotion did not have any significant relationship with consumer behavior. Hong \& Deng (2018) conducted a study to know the factors affecting trust in online healthcare services and concluded that among three kinds of online healthcare services information search requires less amount of trust using online appointment requires moderate level of trust whereas online consultation requires the highest level of trust. Santaso, Bidyati, Hendar (2019) revealed that hedonic motivation does not plays a significant role in online purchase behavior whereas trust, website quality and design play a significant role in purchase intention of customers. Adnan, Hooria (2014) revealed that perceived advantages and psychological factors (trust and security concerns) have a positive influence on consumer buying behavior whereas perceived risk impact consumer buying negatively and website design and hedonic motivation were found to be insignificant.Ofori, Boakye \& Narteh (2016) conducted a study to find factors which influence consumer loyalty 
towards $3 \mathrm{G}$ mobile data service provider and found corporate image, service quality, trust, satisfaction and loyalty are the major factors. Soomro et al. (2012) concluded that ease of booking, e-booking and clearing time to be most significant factors amongst service quality, ease of online booking, boarding and clearing time for preferences in airline industry.

\section{Factors affecting offline and online buying behavior}

In the above fig. the factors affecting offline buying behavior of consumers are shown on the left-hand side while factors affecting online buying behavior are shown on the right-hand side. Factors in the middle are common to both offline and online buying behavior. These factors are convenience, promotion, availability, word of mouth, demography, safety, quality and price.

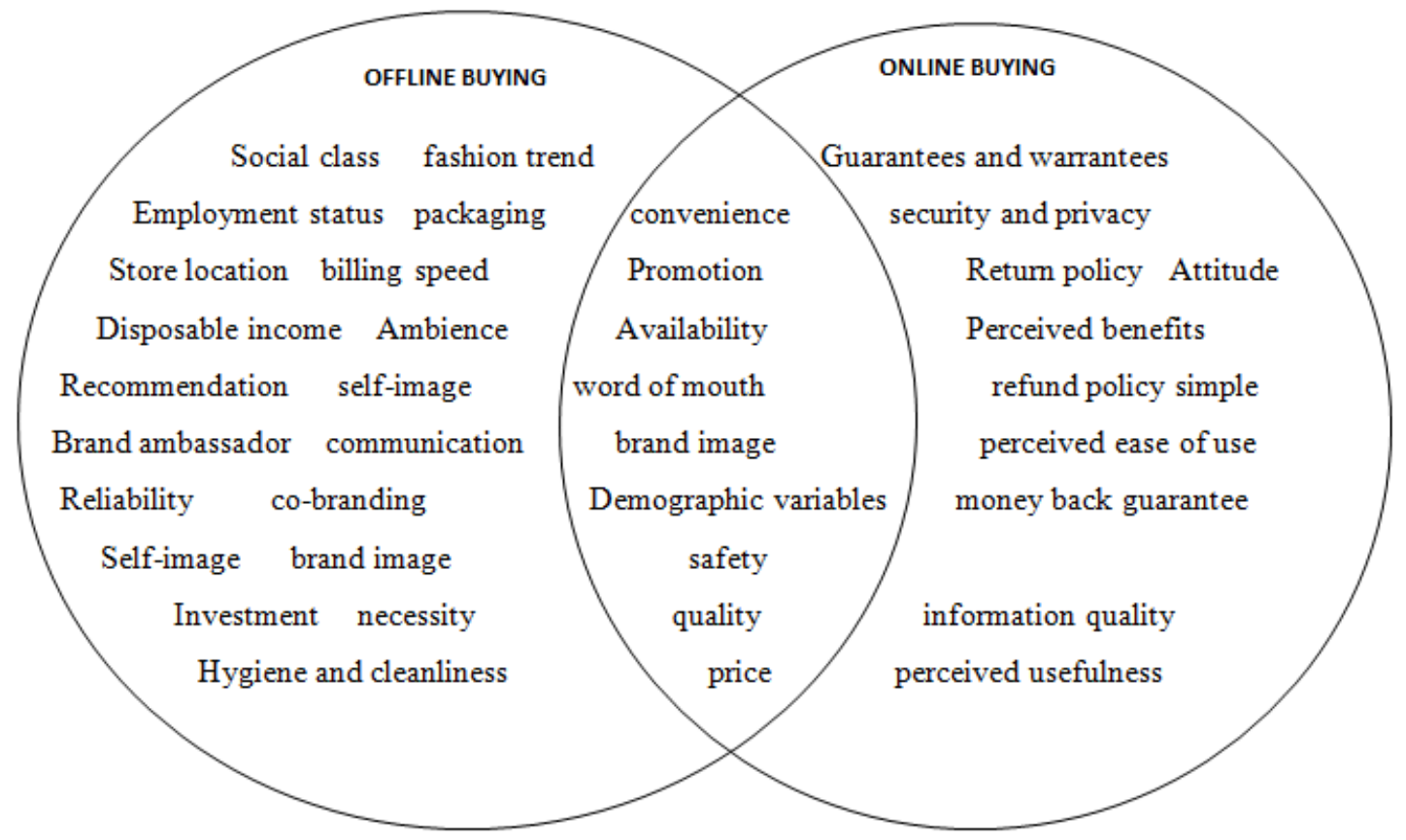

Fig 1: Offline vs. Online Buying Behavior

\section{4: Factors and their references}

\begin{tabular}{|l|l|l|}
\hline S. No & Factors & \multicolumn{1}{c|}{ References/Sources $\mid$} \\
\hline 1 & Convenience & $\begin{array}{l}\text { Soorma et al. (2012), Vikash and Kumar (2017), Islam (2015), Madasu and Rao } \\
\text { (2018), Mahalaxmi and Ranjith (2016), Jadhav et al. (2016) }\end{array}$ \\
\hline 2 & Promotion & Frank (2018), Jonas and Stoica (2014), Jadhav et al. (2016) \\
\hline 3 & Availability & Chopra (2014), Prasad (2014), Chincholkar and Sonwaney (2017) \\
\hline 4 & Brand Image & Peng et al. (2014), Frank (2018), Koshy and Manohar (2017) \\
\hline 5 & Demography & $\begin{array}{l}\text { Lakshmi et al. (2017), Kumar et al. (2014), Rengarajan (2014), Nagra (2013), } \\
\text { Deshmukh and Sanskrity (2016) }\end{array}$ \\
\hline 6 & Safety & Rana and Paul (2017), Vikash and Kumar (2017) \\
\hline 7 & Quality & $\begin{array}{l}\text { Rana and Paul (2017), Ofori and Norteh (2016), Frank (2018), Kumar et al. (2017), } \\
\text { Olise (2015), Zulqarnain (2015), Chincholkar and Sonwaney (2017), Vikash and } \\
\text { Kumar (2017) }\end{array}$ \\
\hline 8 & Price & $\begin{array}{l}\text { Kumar and Namavaram (2016), Sata (2013), Koshy and Manohar (2017), } \\
\text { Zulqarnain (2015), Vadivu (2015), Mahalaxmi and Ranjith (2016), Jadhav et al. } \\
\text { (2016) }\end{array}$ \\
\hline
\end{tabular}

\section{ISM Approach}

ISM (Interpretive structural modelling) is defined as a system which aims at providing assistance to humans by transforming unclear vague mental models to a well-defined model. The model so formed transforms the complex problem or issue to a well-designed pattern. ISM is a technique in which a cluster of variables or factors which are directly or indirectly related are structured into a systematic model. ISM approach is originally propounded by Warfield (1974). 
The steps involved in ISM are given below:

Step 1: Identification of factors

The first step in ISM is to identify the factors which pertains to a situation or issue. In the present paper the various factors which are common in online as well as offline shopping are extracted from the literature. Eight factors taken for study are convenience, promotion, availability, brand image, demography, safety, quality and price.

Step 2: Development of SSIM (Structural self-interaction matrix)

The next step in ISM is to do a pairwise comparison by developing a VAXO table. for this a group of experts is consulted from industry or academia. The VAXO table denotes the inter-relationship between factors ( $i$ and $j)$ as shown in table 2 where:

- $\quad \mathrm{V}$ depicts that factor $\mathrm{i}$ influences factor $\mathrm{j}$

- A depicts that factor $\mathrm{j}$ influences factor $\mathrm{i}$

- $\mathrm{X}$ depicts that both $\mathrm{i}$ and $\mathrm{j}$ influences each other

- $\quad$ depicts that both $\mathrm{i}$ and $\mathrm{j}$ are unrelated

Pairwise comparison of all the eight factor is done with the help of group of experts. About half of the table is left blank as the pairwise comparison of these factors is already done in other half part.

Step 3: Development of Initial Reachability Matrix

SSIM matrix in this step is transformed into reachability matrix by converting the values of SSIM into 1's and 0's as shown in table 3

- If $(i, j)$ entry in SSIM is $V$ then it becomes 1 and if $(j, i)$ is $V$ then it becomes 0

- If $(i, j)$ entry in SSIM is A then it becomes 0 and if $(j, i)$ is $A$ then it becomes 1

- If $(i, j)$ entry in SSIM is X then it becomes 1 and if $(j, i)$ is $X$ then also it becomes 1

- If $(i, j)$ entry in SSIM is $O$ then it becomes 0 and if $(j, i)$ is $O$ then also it becomes 0

The factors of SSIM in this step are numbered from 1 to 8 and assigned 0's and 1's in both direction (i,j) and (j, i). and now the entire table is filled.

Step 4: Development of final Reachability Matrix

After preparing the initial reachability matrix it's transitivity is checked and $1 *$ is used in place of 0 's where there is error. Then a final reachability matrix is prepared as shown in table 4 . Transitivity indicates if factor 1 is related to 2 and factor 2 to 3 then it means 1 is related to 3 .

Step 5: Partitioning the final reachability matrix

In this step the partitioning of final reachability matrix is done by assessing reachability sets and antecedents sets for each factor. Reachability sets includes all the factors which are present in the row of the given factor, it depicts all the factors on which that particular factor is dependent. The antecedent sets include all the factors which are there in the column of that particular factor, it depicts all the factors which that particular factor drives. Intersection sets depicts all the common factors of the reachability and antecedents sets. If the reachability set and intersection set are same then those factors occupy the first level and then all those factors are removed to find the next subsequent levels. In our case there are 5 factors in the first level of partitioning present in iteration 1 , which are $2,4,5,7,8$ they occupy first level in the hierarchy and then these are removed from all three sets that is reachability set, antecedent set and intersection set in the next level partitioning, now the factors left are 1,3 and 6 in which reachability set is same as intersection set and all three occupy $2^{\text {nd }}$ level in the hierarchy. The level of partitioning comes out to be two only as the numbers of factors are limited.

Step 6: Development of conical matrix

A conical matrix is prepared from the reachability matrix by clubbing together the factors of partition levels. Shown in table 5

Step 7: Development of ISM model

An Ism model is developed on the basis of level partitioning where the first level contains all linking factors which are dependent on each other and also drive each other as present on left side of fig 2 . And on the right side of same fig. are independent factors which are convenience, availability and safety, they are not dependent on each other but they help in driving others. In this model independent factors drives linking factors. 
Table 2. SSIM

\begin{tabular}{lllllllll}
\hline & $\begin{array}{l}\text { Pric } \\
\mathrm{e}\end{array}$ & $\begin{array}{l}\text { Qualit } \\
\mathrm{y}\end{array}$ & $\begin{array}{l}\text { Safet } \\
\mathrm{y}\end{array}$ & $\begin{array}{l}\text { Demograph } \\
\mathrm{y}\end{array}$ & $\begin{array}{l}\text { Brand } \\
\text { Image }\end{array}$ & $\begin{array}{l}\text { Availabilit } \\
\mathrm{y}\end{array}$ & $\begin{array}{l}\text { Promotio } \\
\mathrm{n}\end{array}$ & $\begin{array}{l}\text { Convenienc } \\
\mathrm{e}\end{array}$ \\
\hline Convenienc & & & & & & & $\mathrm{O}$ & $\mathrm{O}$ \\
$\mathrm{e}$ & $\mathrm{O}$ & $\mathrm{O}$ & $\mathrm{O}$ & $\mathrm{V}$ & $\mathrm{O}$ & $\mathrm{X}$ & $\mathrm{X}$ \\
Promotion & $\mathrm{V}$ & $\mathrm{O}$ & $\mathrm{O}$ & $\mathrm{X}$ & $\mathrm{X}$ & $\mathrm{A}$ & & \\
Availability & $\mathrm{V}$ & $\mathrm{O}$ & $\mathrm{O}$ & $\mathrm{O}$ & $\mathrm{O}$ & $\mathrm{X}$ & & \\
Brand & & & & & & & \\
Image & $\mathrm{V}$ & $\mathrm{V}$ & $\mathrm{O}$ & $\mathrm{X}$ & $\mathrm{X}$ & & \\
$\begin{array}{l}\text { Demograph } \\
\text { y }\end{array}$ & $\mathrm{X}$ & $\mathrm{X}$ & $\mathrm{A}$ & $\mathrm{X}$ & & & \\
Safety & $\mathrm{O}$ & $\mathrm{V}$ & $\mathrm{X}$ & & & & \\
Quality & $\mathrm{V}$ & $\mathrm{X}$ & & & & & \\
Price & $\mathrm{X}$ & & & & & & & \\
\hline
\end{tabular}

Table 3. Initial Reachability Matrix

\begin{tabular}{lllllllll}
\hline & 1 & 2 & 3 & 4 & 5 & 6 & 7 & 8 \\
\hline 1 & 1 & 0 & 0 & 0 & 1 & 0 & 0 & 0 \\
2 & 0 & 1 & 0 & 1 & 1 & 0 & 0 & 1 \\
3 & 0 & 1 & 1 & 0 & 0 & 0 & 0 & 1 \\
4 & 0 & 1 & 0 & 1 & 1 & 0 & 1 & 1 \\
5 & 0 & 1 & 0 & 1 & 1 & 0 & 1 & 1 \\
6 & 0 & 0 & 0 & 0 & 1 & 1 & 1 & 0 \\
7 & 0 & 0 & 0 & 0 & 1 & 0 & 1 & 1 \\
8 & 0 & 0 & 0 & 0 & 1 & 0 & 0 & 1 \\
\hline
\end{tabular}

Table 4

\begin{tabular}{rcccccccccc}
\hline & 1 & 2 & 3 & 4 & 5 & 6 & 7 & 8 & driving oower \\
\hline 1 & 1 & $1^{*}$ & 0 & $1^{*}$ & 1 & 0 & $1^{*}$ & $1^{*}$ & 6 \\
2 & 0 & 1 & 0 & 1 & 1 & 0 & $1^{*}$ & 1 & 5 \\
3 & 0 & 1 & 1 & $1^{*}$ & $1^{*}$ & 0 & 0 & 1 & 5 \\
4 & 0 & 1 & 0 & 1 & 1 & 0 & 1 & 1 & 5 \\
5 & 0 & 1 & 0 & 1 & 1 & 0 & 1 & 1 & 5 \\
6 & 0 & $1^{*}$ & 0 & $1^{*}$ & 1 & 1 & 1 & $1 *$ & 6 \\
7 & 0 & $1^{*}$ & 0 & $1^{*}$ & 1 & 0 & 1 & 1 & 5 \\
dependence power & 0 & $1^{*}$ & 0 & $1^{*}$ & 1 & 0 & $1 *$ & 1 & 5 \\
\hline
\end{tabular}

Iteration I

\begin{tabular}{|c|c|c|c|c|c|}
\hline Factors & & & Antecedent Set & Intersection Set & Level \\
\hline & 1 & 124578 & 1 & 1 & \\
\hline & 2 & 24578 & 12345678 & 24578 & I \\
\hline & 3 & 23458 & 3 & 3 & \\
\hline & 4 & 24578 & 12345678 & 24578 & I \\
\hline & 5 & 24578 & 12345678 & 24578 & I \\
\hline & 6 & 245678 & 6 & 6 & \\
\hline & 7 & 24578 & 1245678 & 24578 & I \\
\hline & 8 & 24578 & 12345678 & 24578 & I \\
\hline
\end{tabular}

Iteration 2.

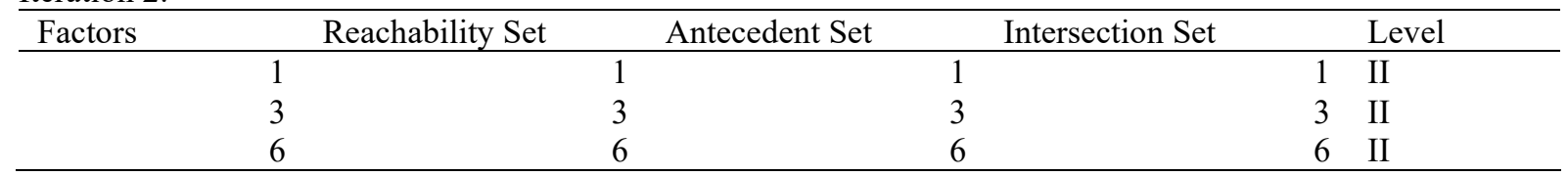


Table 5.

\begin{tabular}{lllllllll}
\hline & 2 & 4 & 5 & 7 & 8 & 1 & 3 & 6 \\
\hline 2 & 1 & 1 & 1 & 1 & 1 & 0 & 0 & 0 \\
4 & 1 & 1 & 1 & 1 & 1 & 0 & 0 & 0 \\
5 & 1 & 1 & 1 & 1 & 1 & 0 & 0 & 0 \\
7 & 1 & 1 & 1 & 1 & 1 & 0 & 0 & 0 \\
8 & 1 & 1 & 1 & 1 & 1 & 0 & 0 & 0 \\
1 & 1 & 1 & 1 & 1 & 1 & 1 & 0 & 0 \\
3 & 1 & 1 & 1 & 0 & 1 & 0 & 1 & 0 \\
6 & 1 & 1 & 1 & 1 & 1 & 0 & 0 & 1 \\
\hline
\end{tabular}

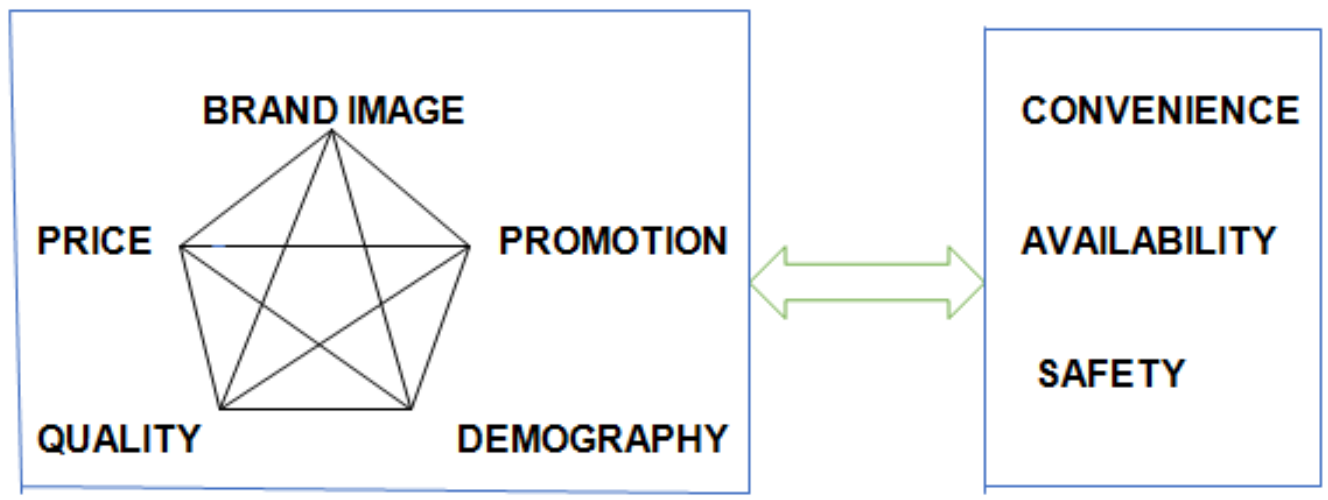

Fig 2 . An ISM model of purchase determinants

\section{MICMAC Analysis}

Matrice d' impact Croises-multiplication applique (cross -impact matrix multiplication to classification) is abbreviated as MICMAC analysis. Based on driving power and dependent power factors can be classified into 4 categories :

1. Autonomous - the factors which have weak drive power as well as weak dependence power are classified as autonomous factors.

2. Dependent -the factors with strong dependence power but weak driving power are classified as dependent factors.

3. Linkage- The factors with strong dependence as well as driving power are classified under linkage factors.

4. Independent factors- the factors with weak dependence power but strong driving power are classified as independent factors.

\section{Driving power}

\begin{tabular}{|c|c|c|c|c|c|c|c|c|}
\hline 8 & & & & & & & & \\
\hline 7 & & & & & & & & \\
\hline 6 & 1,6 & & & & & & & \\
\hline 5 & 3 & & & & & & 7 & $2,4,5,8$ \\
\hline 4 & & & & & & & & \\
\hline 3 & & & & & & & & \\
\hline 2 & & & & & & & & \\
\hline 1 & & & & & & & & \\
\hline & 1 & 2 & 3 & 4 & 5 & 6 & 7 & 8 \\
\hline
\end{tabular}

Dependence power

All the eight factors in MICMAC analysis are placed on the basis of their dependence and driving power in the four quadrants. Factor 2,4,5,7 and 8 occupies place in third quadrant and hence are categorized as linking factors they are dependent on each other and also drive each other. Factor 1,3 and 6 occupies place in $4^{\text {th }}$ quadrant and are categorized as independent factors, they are not dependent on any other factors but all of them drive factor $2,4,5,7$ and 8 .

\section{Conclusion}

The major objectives of this paper are to find out the factors which are common to both online as well as offline buying behavior and to establish an interrelationship among these factors. To cater to this requirement, an ISM 
model is developed with two levels of partitioning, in the first level there are five factors which are promotion, brand image, demography, quality and price. These factors are categorized as linking factors with strong dependence and drive power. Any action on any of these factors will affect other. Further these factors are influenced by the next level factors of partitioning. On the next level of partitioning there are three factors which are convenience, availability and safety. These factors have strong drive power and weak dependence power. They have influence on other factors. Further there are no factors in the quadrant 1 and 2 which means there are no autonomous factors, which are disconnected from the whole system and no dependent factors which are just dependent on others but does not drive others. The ISM model so developed in this paper acts as a tool for marketer to understand and identify the factors of purchase determinants as well as it will serve as literature for future researches in similar area. The ISM model so formed has not been statistically validated.

\section{Limitation}

Some of the important research papers might have been left out for literature review.If the number of factors taken for developing ISM model have been more then the more level of partitioning could have be possible. Further such ISM model could be developed for offline and online buying behavior as well.

\section{References}

Adnan, H. (2014). An analysis of the factors affecting online purchasing behavior of Pakistani consumers. International Journal of Marketing Studies, 6(5), 133.

Altekar, D., \& Keskar, A. (2014). A Study of the Factors Impacting the Buying Decision Process Vis-à-vis Specified Consumer Durables in NOIDA. Journal of General Management Research, ISSN, 2348, 2869.

Attri, R., Dev, N., \& Sharma, V. (2013). Interpretive structural modelling (ISM) approach: an overview. Research Journal of Management Sciences, 2319, 1171.

Bansal, M., Vij, A. K., \& Nayyar, R. (2019). Flexible Mental Models and Collective Wisdom Through Social Media: An Interpretive Structural Modeling Approach. Journal of Operations and Strategic Planning, 2(1), 65-84.

Chopra, A. N. Factors affecting Purchase behavior of Women grocery con-sumer-An Insight.

Deshmukh, G. K., Joseph, S., \& Sanskrity, J. (2016). Online shopping in India: An enquiry of consumers world. IOSR Journal of Business and Management, 18(1), 28-33.

Diallo, M. F., Chandon, J. L., Cliquet, G., \& Philippe, J. (2013). Factors influencing consumer behavior towards store brands: evidence from the French market. International Journal of Retail \& Distribution Management.

Emir, A., Halim, H., Hedre, A., Abdullah, D., Azmi, A., \& Kamal, S. B. M. (2016). Factors influencing online hotel booking intention: A conceptual framework from stimulus-organism-response perspective. International Academic Research Journal of Business and Technology, 2(2), 129-134.

Furaiji, F., Łatuszyńska, M., \& Wawrzyniak, A. (2012). An empirical study of the factors influencing consumer behavior in the electric appliances market. Contemporary Economics, 6(3), 76-86.

Gomathy, C., \& Devi, N. Y. (2015). Consumer behavior in purchase of Gold Jewellery-An analytical study. International Journal of Multidisciplinary Research and Development, 2(7), 103-106.

Hashmi, H., Attiq, S., \& Rasheed, F. (2019). Factors Affecting Online Impulsive Buying Behavior: A Stimulus Organism Response Model Approach. Market Forces, 14(1).

Hassan, H. G. (2018). The Impact of Social Media on Consumer Behavior during Product Purchase Decision Making Process. EPH-International Journal of Business \& Management Science (ISSN: 2208-2190), 4(3), 9-32.

Horsu, E. N., \& Yeboah, S. T. (2015). Influence of service quality on customer satisfaction: A study of minicab taxi services in Cape Coast, Ghana. International journal of economics, commerce and management, 3(5), $1451-1464$

Iqbal, M. M., \& Showrav, D. G. Y. (2018). Factors influencing consumer buying behavior: a study on cosmetic products in Dhaka city.

Javadi, M. H. M., Dolatabadi, H. R., Nourbakhsh, M., Poursaeedi, A., \& Asadollahi, A. R. (2012). An analysis of factors affecting on online shopping behavior of consumers. International Journal of Marketing Studies, 4(5), 81.

Jayasubramanian, P., Sivasakthi, D., \& Ananthi Priya, K. (2015). A study on customer satisfaction towards online shopping. International Journal of Applied Research, 1(8), 489-495.

Jun, G., \& Jaafar, N. I. (2011). A study on consumers' attitude towards online shopping in China. International Journal of Business and Social Science, 2(22), 122-132.

Khuong, M. N., \& Duyen, H. T. M. (2016). Personal factors affecting consumer purchase decision towards men skin care products-A study in Ho Chi Minh city, Vietnam. International Journal of Trade, Economics and Finance, 7(2), 44-50.

Koshy, L., \& Manohar, S. J. (2017). Factors influencing the buying behavior of face care products among youth. 
International Journal in Management \& Social Science, 5(1), 63-72.

Kumar, A. A., \& Babu, S. (2014). Factors influencing consumer buying behavior with special reference to dairy products in Pondicherry state. International Monthly Refereed Journal of Research in Management and Technology, 3(1), 65-73.

Kumar, A. H., John, S. F., \& Senith, S. (2014). A study on factors influencing consumer buying behavior in cosmetic products. International Journal of Scientific and Research Publications, 4(9), 1-6.

Kumar, A. H., John, S. F., \& Senith, S. (2014). A study on factors influencing consumer buying behavior in cosmetic products. International Journal of Scientific and Research Publications, 4(9), 1-6.

Kumar, P. K., \& Kumar, N. R. (2016). A study on factors influencing the consumers in selection of cab services. International Journal of Social Science and Humanities Research, 4(3), 557-561.

Kumar, S., \& Bhatnagar, D. Factors Affecting Customer Satisfaction of Food and Beverage Outlets-A Study of Food and Beverage Outlets between Amritsar and Jalandhar.

Lakshmi, V. V., Niharika, D. A., \& Lahari, G. (2017). Impact of gender on consumer purchasing behavior. IOSR Journal of Business and Management, 19(8), 33-36.

Legeza, D. G., Brunner, T., Kerimova, Y. K., Kulish, T. V., \& Konovalenko, A. S. (2019). A model of consumer buying behavior in relation to eco-intelligent products in catering. Innovative Marketing, 15(1), 54-65.

Lim, Y. J., Osman, A., Salahuddin, S. N., Romle, A. R., \& Abdullah, S. (2016). Factors influencing online shopping behavior: the mediating role of purchase intention. Procedia economics and finance, 35(5), 401410.

Mahalaxmi, K. R., \& Ranjith, P. (2016). A Study on Impact of Digital Marketing in Customer Purchase Decision in Trichy. International Journal for Innovative Research in Science \& Technology, 2(10), 332-338.

Mashao, E. T., \& Sukdeo, N. (2018). Factors that influence consumer behavior in the purchase of durable household products. In Proceedings of the International Conference on Industrial Engineering and Operations Management. Paris, France, July (pp. 26-27).

Mittal, S. (2016). A Study of Factors Influencing Buying Behavior in the Indian White Goods Industry for Indore City. IOSR Journal of Business and Management, 18(1), 34-38.

Noranee, S., Badar, M. A. S., Aziz, R. A., Munir, Z. A., \& Sundram, V. P. K. (2019). Relationship between Website Determinants and Customer Switching in a Hypermarket Online Shopping: Customer Trust as a Mediator. Journal of Reviews on Global Economics, 8, 998-1005.

Ofori, K. S., Boakye, K., \& Narteh, B. (2018). Factors influencing consumer loyalty towards $3 \mathrm{G}$ mobile data service providers: evidence from Ghana. Total Quality Management \& Business Excellence, 29(5-6), 580598.

Olise, M. C., Okoli, M. I., \& Ekeke, J. N. (2015). Factors influencing customers patronage of fast food restaurants. International Journal of Economics, Commerce and Management, 3(11), 686-701.

Pecotić, M., Bazdan, V., \& Samardžija, J. (2014). Interior design in restaurants as a factor influencing customer satisfaction. RIThink, 4, 10-14.

Peng, L., Wang, H., He, X., Guo, D., \& Lin, Y. (2014). Exploring factors affecting the user adoption of call-taxi App. ACIS.

Prasad, G. H. S. (2014). Factors influencing buying behavior of a selected apparel retailer's customers. Symbiosis Centre for Management Studies, Pune Annual Research Journal of Symbiosis Centre for Management Studies, Pune, 1, 41-55.

Raj, M. P. M., Sasikumar, J., \& Sriram, S. (2013). A Study of Customers Brand Preference in SUVS and MUVS: Effect on Marketing Mix Variables. International Referred Research Journal, 4(1), 48-58.

Rana, J., \& Paul, J. (2017). Consumer behavior and purchase intention for organic food: A review and research agenda. Journal of Retailing and Consumer Services, 38, 157-165.

Rao, M. B., Hymavathi, C. L., \& Rao, M. M. (2018). Factors affecting female consumer's online buying behavior. Academy of Marketing Studies Journal.

Rashid, I. M. A., Abdullah, M. F. S., Yusuf, B. N. M., \& Shaari, M. S. (2016). Impact of Service and Food Quality on Customer Satisfaction among Generation Y for the Fast Food Restaurant in Malaysia. International Journal of Information, Business and Management, 8(1), 51.

Raunaque, N., Zeeshan, M., \& Imam, M. A. (2016). Consumer Perception towards Online Marketing in India. International Journal of Advanced Engineering, Management and Science, 2(8).

Sata, M. (2013). Factors affecting consumer buying behavior of mobile phone devices. Mediterranean Journal of Social Sciences, 4(12), 103.

Shende, V. (2014). Analysis of research in consumer behavior of automobile passenger car customer. International Journal of Scientific and Research Publications, 4(2), 1.

Sindhwani, R., \& Malhotra, V. (2017). Modelling and analysis of agile manufacturing system by ISM and MICMAC analysis. International Journal of System Assurance Engineering and Management, 8(2), 253-263.

Singh, D. S. (2015). A Study of Perfumes Buying Behavior of Consumers in India. Journal of Advanced Research 
in Operational \& Marketing Management.

Thakur, S., \& Aurora, R. (2015). Consumer perception: A study on e-marketing. International Journal of Recent Research Aspects, 2(2), 256-262.

Vaghela, P. (2014). A study on consumer perception towards online shopping. International journal of Marketing and Technology, 4(12), 200-210.

Vaghela, P. FACTORS AFFECTING ONLINE SHOPPING BEHAVIOR IN SURAT CITY.

Yapa, U. A. (2017). The Impact of Social Media on Brand Awareness (With Special Reference to Facebook Use in Fast Moving Consumer Goods in Sri Lanka). International Journal of Engineering and Management Research (IJEMR), 7(5), 262-272.

Younus, S., Rasheed, F., \& Zia, A. (2015). Identifying the factors affecting customer purchase intention. Global Journal of Management and Business Research.

Zulqarnain, H., Zafar, A. U., \& Shahzad, M. (2015). Factors that affect the choice of Consumers in selecting Retail Store, for Grocery Shopping. International Journal of Multidisciplinary and Current Research, 3(1), 11671172. 